\title{
Differential effectiveness of anti-CD8 treatment on ongoing graft-versus-host reactions in mice
}

\author{
WA Noort, R Benner and HFJ Savelkoul \\ Department of Immunology, Erasmus University, Rotterdam
}

Received 9 January 1996; accepted 19 January 1996

\begin{abstract}
Analysis of T cell subsets in the spleen during graft-versus-host (GVH) reactions in a fully allogeneic mouse strain combination demonstrated that first $\mathrm{CD}^{+} \mathrm{T}$ cells become activated, and initiate the GVH reaction. Subsequently, $\mathrm{CD}^{+} \mathrm{T}$ cells become involved. Here we show that anti-CD8 treatment on day +3 resulted in a significant increase in survival, while early treatment (day -1 or day +1 ) did not. Acute GVH reactions were induced (day 0) in lethally irradiated (C57BL/6 $\times \mathrm{CBA} / \mathrm{J}) \mathrm{F} 1\left(\mathrm{H}-2^{\mathrm{th}}\right)$ mice by intravenous injection of BALB/c (H-2d) spleen and lymph node cells $\left(3.6 \times 10^{7}\right)$ within $24 \mathrm{~h}$ after irradiation. Mice were treated intraperitoneally with a single optimally depleting dose of rat anti-CD8 (YTS 169.4) or untreated. Symptoms of GVHD became obvious 6 days after reconstitution, and mortality started at day 8 . The mutual influence of $\mathrm{CD}^{+}$and $\mathrm{CD} 8^{+} \mathrm{T}$ cells in the development of GVHD becomes apparent from our data, and demonstrates that GVHD lethality can be caused by $\mathrm{CD}^{+} \mathrm{T}$ cells as well as by $\mathrm{CD} 4^{+} \mathrm{T}$ cells.
\end{abstract}

\section{Introduction}

As became clear from allogeneic bone marrow transplantation in animals, mature $\mathrm{T}$ cells in the marrow inoculum can cause graft-versus-host disease (GVHD). ${ }^{1}$ When these T cells recognize foreign histocompatibility antigens expressed on host tissue, a systemic cellular immune response develops. Both $\mathrm{CD}^{+}$ and $\mathrm{CDB}^{+} \mathrm{T}$ cells are involved in GVHD in mice and humans, depending on the MHC or non-MHC differences between donor and recipient. We formerly demonstrated that in the fully allogeneic $\mathrm{BALB} / \mathrm{c}-(\mathrm{C} 57 \mathrm{BL} \times \mathrm{CBA}) \mathrm{F} 1$ strain combination transplantation of purified $\mathrm{CD}^{+} \mathrm{T}$ cells induced lethal GVHD, whereas purified $\mathrm{CD} 8^{+} \mathrm{T}$ cells did not, suggesting a major role for the $\mathrm{CD} 4^{+} \mathrm{T}$ cell subset. ${ }^{2}$

Flow cytometric analysis of $T$ cell subsets in the spleen of the (C57BL $\times$ CBA)F1 recipients early after reconstitution demonstrated a strong increase in the number of $\mathrm{CD} 4^{+} \mathrm{T}$ cells peaking on day 4 or 5 . Also the number of $\mathrm{CDB}^{+} \mathrm{T}$ cells increased strongly, but consistently peaked $1-2$ days later. $\mathrm{CD}^{+} \mathrm{T}$ cells then became the predominant $\mathrm{T}$ cell subset. Since the first signs of acute GVHD became obvious 6 days after

Address for correspondence: WA Noort, Department of Immunology, Erasmus University, P.O. Box 1738, 3000 DR Rotterdam, The Netherlands. reconstitution, we concluded that in this mouse strain combination subsequent waves of $\mathrm{CD} 4^{+}$and $\mathrm{CD} 8^{+} \mathrm{T}$ cells preceded the development of clinically overt GVHD. ${ }^{3}$

Anti-CD4 treatment given 1 day before reconstitution was able to prevent the development of lethal GVHD, whereas anti-CD8 treatment was not. Flow cytometric analysis of the spleen of the recipient mice after allogeneic reconstitution and anti-CD4 monoclonal antibody (mAb) treatment revealed that not only was the number of $\mathrm{CD}^{+} \mathrm{T}$ cells reduced, but also the number of $\mathrm{CD} 8^{+} \mathrm{T}$ cells. ${ }^{4}$ These data suggest that by virtue of their interleukin 2 (IL-2) production ${ }^{2}$ the activated $\mathrm{CD}^{+} \mathrm{T}$ cells likely account for the activation and proliferation of the $\mathrm{CD8}^{+} \mathrm{T}$ cells. These results do not reveal the role of the $\mathrm{CD} 8^{+}$ $T$ cells in the clinical symptoms of GVHD, although our finding that a strong increase in the number of $\mathrm{CD} 8^{+} \mathrm{T}$ cells preceded the development of overt GVHD suggests that they are important. ${ }^{3}$

\section{Objective}

In this study we further investigated whether our assumption that $\mathrm{CD}^{+} \mathrm{T}$ cells do play an important role in the effector phase of graft-versus-host disease (GVHD) could be affirmed. To this end, we postponed anti-CD8 treatment to days of ongo- 
ing GVHD and determined the effect on survival as well as on kinetics of $T$ cell subset populations in the spleen by flow cytometry.

\section{Materials, methods and experimental design}

GVH reactions were induced in lethally irradiated (10 Gy) $(\mathrm{C} 57 \mathrm{BL} / 6 \times \mathrm{CBA} / \mathrm{J}) \mathrm{F} 1\left(\mathrm{H}-2^{\mathrm{b} / \mathrm{k}}\right)$ mice by intravenous injection (day 0 ) of a mixture of $3 \times 10^{7}$ BALB/c $\left(\mathrm{H}-2^{d}\right)$ spleen cells with $6 \times 10^{6} \mathrm{BALB} / \mathrm{c}$ lymph node cells within $24 \mathrm{~h}$ after irradiation. Mice were treated with one optimally depleting dose of $200 \mu \mathrm{g}$ or even $1 \mathrm{mg}$ of highly purified rat anti-CD8 IgG2b mAb (YTS 169.4) 5 ,6 4 after irradiation, but before the reconstitution (day -1 ), or on day $+1,+3,+5$ or +7 . Anti-CD4 treatment was performed with $1 \mathrm{mg}$ of YTS $191.1,{ }^{6}$ an IgG2b $\mathrm{mAb}$. Mice were examined daily for the development of signs of acute GVHD. Mortality started at day 8. Irradiated control mice reconstituted with syngeneic cells survived $>250$ days without signs of disease. Radiation controls died between days 10 and 22.

Flow cytometric analyses of the recipient spleen cells were performed 4, 5 and 7 days after induction of GVHD. On these days, cell suspensions of recipient spleens were prepared in buffered salt solution. Nucleated cell concentrations were determined with a Coulter Counter model ZB1. From these spleen cell suspensions $\left(10^{7}\right.$ nucleated cells $\left./ \mathrm{ml}\right) 25 \mu 1$ was used for staining. The background staining was determined by staining with FITC (fluorescein isothiocyanate)-labelled rabbit anti-rat $\mathrm{F}\left(\mathrm{ab}^{\prime}\right)_{2}$ fragments alone. $\mathrm{CD3}^{+}, \mathrm{CD8}^{+}$and $\mathrm{CD}^{+} \mathrm{T}$ cells were determined by direct staining with FITC-labelled KT3, 53-6.72, and H129.19, respectively. Cells were also stained with a phycoerythrin-labelled Thy-1.2 mAb (30H12). Forward and side scatter settings were gated on leucocyte populations excluding red cells and debris. A total of 4000 cells was analyzed for each determination.

\section{Results}

Survival after anti-CD8 treatment $(200 \mu \mathrm{g})$ on day $-1,+1$ or +3

Postponing anti-CD8 treatment of recipients to day 3 after reconstitution, which is the start of the massive proliferation of $\mathrm{CD}^{+}$and $\mathrm{CD} 8^{+} \mathrm{T}$ cells, resulted in a significantly improved survival as compared to treatment on day -1 or day +1 and to untreated mice (Figure 1). However, also after postponed anti-CD8 treatment all mice eventually died.

\section{Flow cytometric analysis of $T$ cell subsets in the} spleen after treatment on day -1

After anti-CD8 treatment on day -1 , low numbers of $\mathrm{CD} 8^{+} \mathrm{T}$ cells were found in the spleen on day 4 as well as on days 5 and 7 compared to untreated mice (Figure 2). When mice were treated on day +3 similar results were obtained (Figure 3 ). Moreover, more $\mathrm{CD}^{+} \mathrm{T}$ cells were found on days 4,5 and 7 compared to untreated mice (Figure 2). In Figure 2 the indicated numbers reflect the additional $\mathrm{CD} 4^{+} \mathrm{T}$ cells above the control. On day 7 this increase in $\mathrm{CD} 4^{+} \mathrm{T}$ cells was statistically significant from untreated mice $(P<0.05)$.

By comparing Figures 2 and 3, a difference in kinetics of $\mathrm{CD}^{+} \mathrm{T}$ cells was observed at several time points. The increase in $\mathrm{CD}^{+} \mathrm{T}$ cells occurred much more quickly in the experiment depicted in Figure 3. Already on day 4 a stalistically significant increase in $\mathrm{CD} 4^{+} \mathrm{T}$ cells $\left(7 \times 10^{6}\right)$ was found as compared to untreated mice.

\section{Flow cytometric analysis of $\mathrm{T}$ cell subsets in the} spleen after treatment on day +3

After anti-CD8 treatment on day +3 very low numbers of $\mathrm{CD}^{+} \mathrm{T}$ cells were found on days 4 and 7 (Figure 3). Moreover, fewer $\mathrm{CD} 4^{+} \mathrm{T}$ cells were found on days 4 and 7 as compared to treatment on day -1 . Half the number and 0.7 times the number of $\mathrm{CD} 4^{+} \mathrm{T}$ cells $(P<0.05)$ were found on days 4 and 7 , respectively, after treatment on day +3 compared to

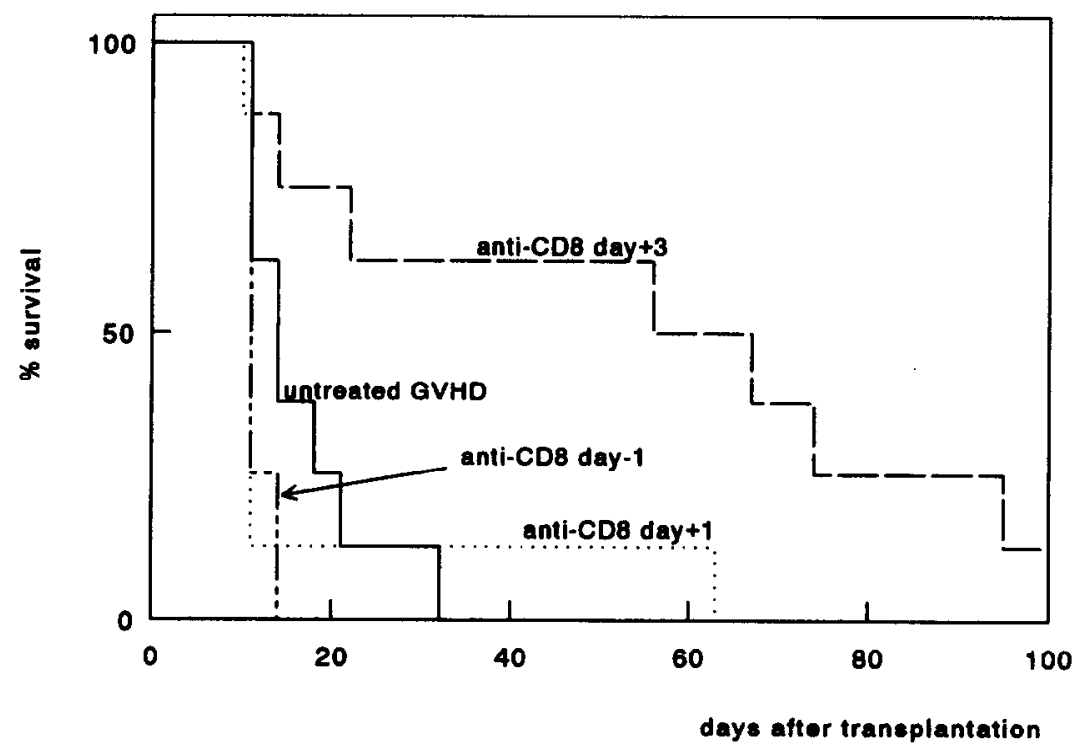

Figure 1 The effect of the moment of anti-CD8 treatment on the survival of lethally irradiated (10 Gy) (C57BL/6 $\times$ CBA)F1 (H-2 ${ }^{\text {b/k }}$ ) recipients reconstituted with a mixture of $3 \times 10^{7} \mathrm{BALB} / \mathrm{c}\left(\mathrm{H}-2^{\mathrm{d}}\right)$ spleen cells and $6 \times 10^{6} \mathrm{BALB} / \mathrm{c}$ lymph node cells within $24 \mathrm{~h}$ after irradiation. Mice were untreated or treated with a single dose (i.p.) of anti-CD8 $\operatorname{lgG} 2 \mathrm{~b} 1$ day before reconstitution, or at day +1 or +3 (each group: $n=8$ ). 


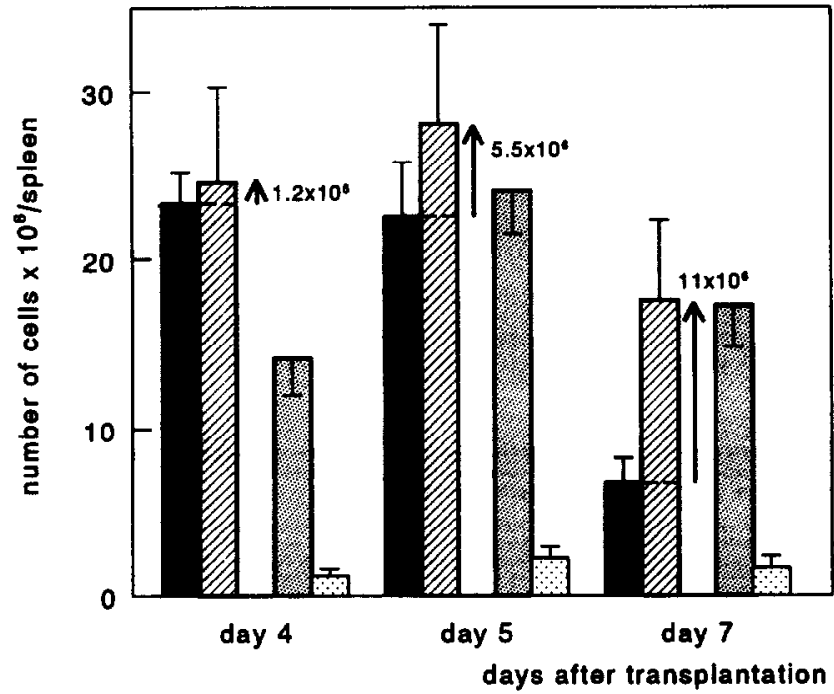

Figure 2 FACScan analysis of $\mathrm{CD}^{+}(\square)$ and $\mathrm{CD}^{+} \mathrm{T}$ cells $(\varangle)$ from spleen cell suspensions of (C57BL/6 $\times$ CBA)F1 mice 4,5 and 7 days after GVHD induction (day 0) by injection of a mixture of $3 \times 10^{7}$ spleen cells and $6 \times 10^{6}$ lymph node cells of BALB/c mice $\left(\mathrm{H}-2^{d}\right)$. Similarly $\mathrm{CD}^{+}(\mathrm{W})$ and $\mathrm{CD}^{+}(\mathrm{B}) \mathrm{T}$ cells were analyzed after treatment with a single dose of $200 \mu \mathrm{g}$ of anti-CD8 IgG2b (day -1). At day 4,5 and 7 we found $1.2,5.5$ and $11 \times 10^{6}$, respectively, more $\mathrm{CD} 4^{+} \mathrm{T}$ cells in anti-CD8 treated mice than in untreated mice. On day 7 this increased number of $\mathrm{CD}^{+} \mathrm{T}$ cells was significantly different from untreated mice $(P<0.05) \quad(n=4$ for each day and each treatment).

treatment on day -1 . The number of $\mathrm{CD}^{+} \mathrm{T}$ cells on day 4 was comparable with that of untreated mice. A slight but statistically significant increase in the number of $\mathrm{CD}^{+} \mathrm{T}$ cells $(P<0.05)$ was seen on day 7 compared to untreated mice.

\section{Survival after treatment with a single high dose $(1 \mathrm{mg}$ ) of anti-CD8 or anti-CD4 $\mathrm{mAb}$ on days -1 , $+3,+5$ or +7}

Treatment of mice on days $-1,+3,+5$ or +7 with $1 \mathrm{mg}$ of anti-CD8 mAb demonstrated that only after treatment on day +3 was there a significant improvement in survival (Figure $4 a)$. Moreover, treatment with this high dose of anti-CD8 $\mathrm{mAb}$ resulted in a $60 \%$ survival at 100 days.

Treatment of mice with a single high dose $(1 \mathrm{mg})$ of antiCD4 mAb on day -1 or +3 resulted in survival of all mice. Treatment on day +5 or +7 did not have any effect on survival (Figure 4b).

\section{Discussion}

This is a first study describing the kinetics of $\mathrm{CD}^{+}$and $\mathrm{CD}^{+}$ $T$ cells during the development of GVHD and the effect of anti-CD8 and anti-CD4 treatment on these kinetics in relation to the progress of the disease. We demonstrate that anti-CD8 treatment of recipients on day 3 after reconstitution resulted in a significantly improved survival as compared to treatment on day -1 or day +1 and to untreated mice (Figure 1). Treatment postponed to day +5 or +7 after transplantation, however, had no effect on the development of the disease (Figure 4a). Eventually all mice died after postponed anti-CD8 treatment when a dose of $200 \mu \mathrm{g}$ was used. This finding confirms our hypothesis that $\mathrm{CD}^{+} \mathrm{T}$ cells play an essential role in the effec- number of cells $\times 10 \% /$ spleen

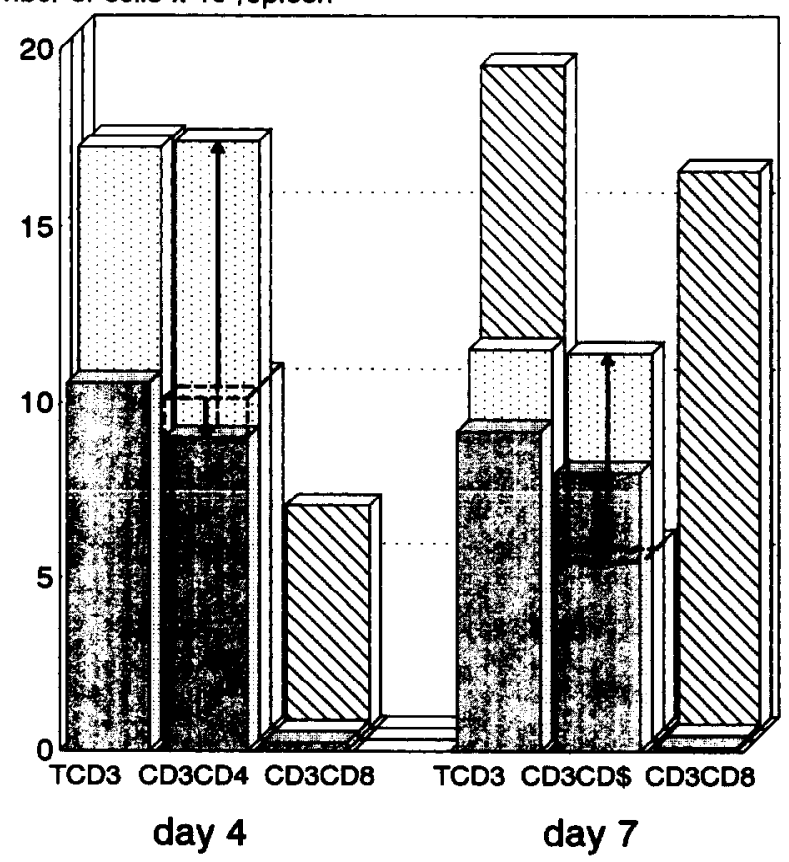

Figure $3(\mathrm{D})$ FACScan analysis of spleen cell suspensions of (C57BL/6 $\times$ CBA)F1 mice 4 and 7 days after GVHD induction (day 0 ) by injection of a mixture of $3 \times 10^{7} \mathrm{BALB} / \mathrm{c}$ spleen cells and $6 \times$ $10^{6} \mathrm{BALB} / \mathrm{c}$ lymph node cells. Similar recipients were treated with a single dose of $200 \mu \mathrm{g}$ of anti-CD8 IgG2b on day -1 or (\$) on day $+3(\square)$. On days 4 and 7 we found 7 and $5.7 \times 10^{6}$, respectively, more $\mathrm{CD}^{+} \mathrm{T}$ cells in anti-CD8 day -1 treated mice compared to untreated mice. For anti-CD8 day +3 treated mice we found on day 4 a comparable number and, on day $7,2.6 \times 10^{6}$ more $\mathrm{CD4}^{+} \mathrm{T}$ cells compared to untreated mice. These differences were all statistically significant $(P<0.05)(n=4$ for each day and each treatment).

tor phase, and that a beneficial effect on survival can only be observed when the $\mathrm{CD} 8^{+} \mathrm{T}$ cells are depleted at the start of the effector phase.

Three possibilities can explain the improved survival after anti-CD8 treatment at day 3. Firstly, it is possible that the $\mathrm{CD}^{+} \mathrm{T}$ cells have a different role in the induction and effector phase of GVHD. Depletion of $\mathrm{CD}^{+} \mathrm{T}$ cells, therefore, could have a different effect on survival dependent on the moment of anti-CD8 treatment. Secondly, if a few $\mathrm{CD}^{+} \mathrm{T}$ cells 'escape' the depleting effect of the mAb or if the mAb has a short half-life, early injection of the mAb cannot completely prevent the development of effector $\mathrm{CD}^{+} \mathrm{T}$ cells at a later stage. Injection of anti-CD8 mAb 4 days later (day +3 ), on the other hand, would be expected to result in lower numbers of $\mathrm{CDB}^{+} \mathrm{T}$ cells in the effector phase of GVHD. This would be consistent with the observed improvement in survival (Figure 1). Flow cytometric analyses, however, demonstrated that only few $\mathrm{CD} 8^{+} \mathrm{T}$ cells escaped from the depleting $\mathrm{mAb}$ (Figure 2). Moreover, after treatment on day -1 an equally low number of $C D 8^{+} T$ cells was found on days 4,5 and 7 (Figure 2) as in mice treated on day +3 (Figure 3).

A third explanation is focused on the involvement of the $\mathrm{CD4}^{+} \mathrm{T}$ cell. We propose that cytokines produced by $\mathrm{CD}^{+} \mathrm{T}$ cells (e.g. IL-2) ${ }^{7}$ are being consumed for activation and proliferation of $\mathrm{CD}^{+}$and $\mathrm{CD}^{+} \mathrm{T}$ cells in GVHD, but after antiCD8 treatment just for $\mathrm{CD}^{+} \mathrm{T}$ cells alone. This is based on the data of Figure 2, showing more $\mathrm{CD} 4^{+} \mathrm{T}$ cells on days 4 , 


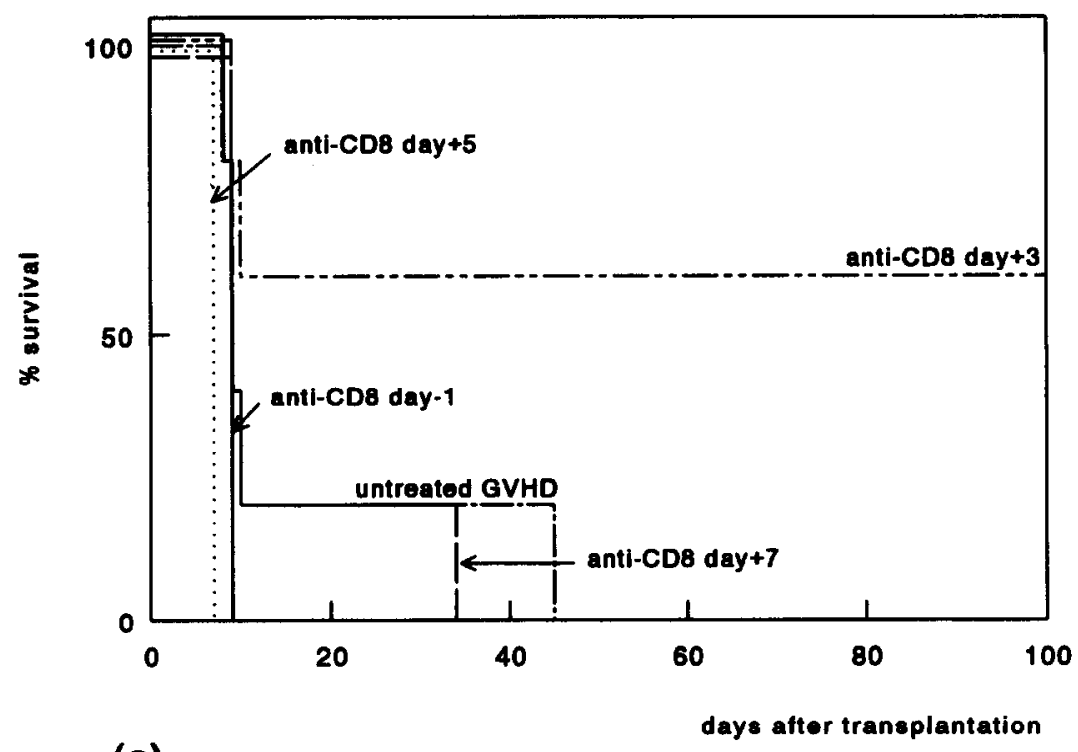

(a)

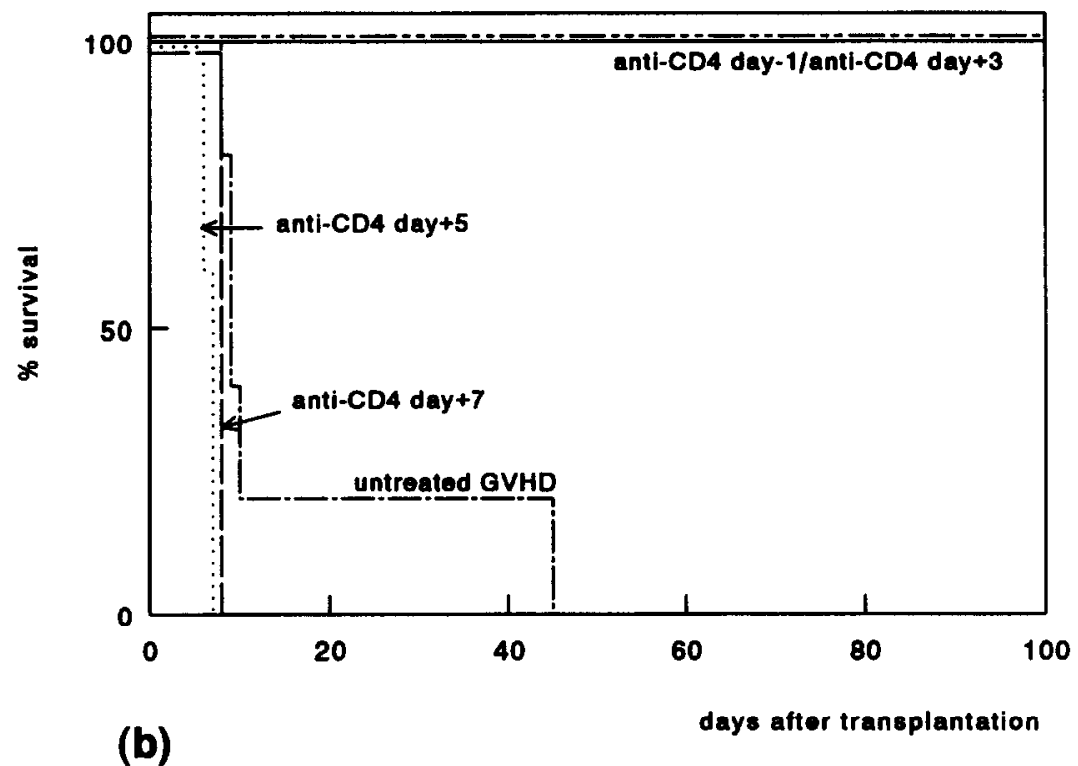

Figure 4 (a) Effect of the moment of anti-CD8 treatment and (b) effect of the moment of anti-CD4 treatment on survival. Lethally irradiated (C57BL/6 $\times$ CBA)F1 recipients were reconstituted with a mixture of $3 \times 10^{7} \mathrm{BALB} / \mathrm{c}$ spleen cells and $6 \times 10^{6} \mathrm{BALB} / \mathrm{c}$ lymph node cells within $24 \mathrm{~h}$ after irradiation. Mice were untreated or treated with a single dose (i.p.) of $1 \mathrm{mg}$ of $\mathrm{mAb} 4 \mathrm{~h}$ after irradiation and thus 1 day before reconstitution, or on day $+3,+5$ or +7 (each group: $n=5$ ).

5 and $7\left(1.2,5.5\right.$ and $11 \times 10^{6}$, respectively) after anti-CD8 treatment on day -1 than in untreated mice. It is likely that anti-CD8 treatment on day +3 may result in a lower number of $\mathrm{CD}^{+} \mathrm{T}$ cells than treatment on day -1 or day +1 after reconstitution, since until then cytokines are being used for activation and proliferation of $\mathrm{CD} 4^{+} \mathrm{T}$ cells as well as $\mathrm{CD} 8^{+}$ $T$ cells. Experiments were performed to test this hypothesis. These showed that after treatment on day +3 the number of $\mathrm{CD}^{+} \mathrm{T}$ cells was significantly lower than after treatment on day -1 (Figure 3). Moreover, compared to untreated mice, a slight increase in the number of $\mathrm{CD}^{+} \mathrm{T}$ cells was seen on day 7. This increase of $\mathrm{CD}^{+} \mathrm{T}$ cells in combination with the complete absence of $\mathrm{CD}^{+} \mathrm{T}$ cells after treatment is probably insufficient to cause death at that particular moment but merely postpones GVH lethality (Figure 1).
In summary, $\mathrm{CD} 8^{+} \mathrm{T}$ cells do not escape from the depleting effect of anti-CD8 $\mathrm{mAb}$, at least not during the first 8 days after injection. Depleting the $\mathrm{CD} 8^{+} \mathrm{T}$ cells by $\mathrm{mAb}$ injection shortly before reconstitution results in an increase of the number of $\mathrm{CD} 4^{+} \mathrm{T}$ cells. Under these conditions, the $\mathrm{CD} 4^{+} \mathrm{T}$ cells probably can take over the role of the $\mathrm{CD}^{+} \mathrm{T}$ cell in the effector phase of GVHD, since no difference in survival was observed between anti-CD 8 treated (day -1 or +1 ) and untreated mice. Anti-CD8 treatment on day +3 after reconstitution shortens the period for the CD4 ${ }^{+} \mathrm{T}$ cells to expand. Thereby the role of the $\mathrm{CD} 4^{+} \mathrm{T}$ cells in the effector phase is probably limited and the onset of deaths by GVHD is postponed. The question arises whether this postponed death is actually caused by a subsequent increase in $\mathrm{CD4}^{+} \mathrm{T}$ cells or an activation of $\mathrm{CD}^{+} \mathrm{T}$ cells by $\mathrm{CD}^{+} \mathrm{T}$ cells once the anti-CD8 mAb is cle- 
ared from the circulation. As treatment with a single high dose $(1 \mathrm{mg}$ ) of anti-CD8 mAb resulted in $60 \%$ survival at 100 days (Figure 4a), we suggest that the anti-CD8 mAb prevents the activation of $\mathrm{CD}^{+} \mathrm{T}$ cells by $\mathrm{CD} 4^{+} \mathrm{T}$ cells. Thus the development of clinical symptoms of GVHD is limited. Together these data show the mutual influence of $\mathrm{CD}^{+}$and $\mathrm{CD} 8^{+} \mathrm{T}$ cells in the development of GVHD, and demonstrate that GVHD lethality can be caused by $\mathrm{CD}^{+} \mathrm{T}$ cells as well as by $\mathrm{CD}^{+}$ $\mathrm{T}$ cells.

\section{References}

1 Korngold R. Biology of graft-vs.-host disease. Am J Pediatr Hematol Oncol 1993; 15: 18-27.

2 Knulst AC, Bril-Bazuin C, Benner R. Prevention of lethal graftversus-host disease by a single low dose of anti-T cell monoclonal antibody to the allograft recipients. Eur J Immunol 1991; 21: 103-107.

3 Knulst AC, Tibbe GJM, Noort WA, Benner R, Savelkoul HFJ. Prevention of lethal graft-versus-host disease in mice by monoclonal antibodies directed to $T$ cells or their subsets. I. Evidence for the induction of a state of tolerance based on suppression. Bone Marrow Transplant 1994; 13: 293-301.

4 Knulst AC, Noort WA, Tibbe GJM, Benner R, Savelkoul HFJ. Prevention of lethal graft-versus-host disease in mice by monoclonal antibodies directed to $\mathrm{T}$ cells or their subsets. II. Differential effectiveness of IgG2a and IgG2b isotypes of anti-CD3 and antiCD4 moAb. Bone Marrow Transplant 1994; 14: 535-43.

5 Savelkoul HFJ, Vossen ACTM, Breedland EG, Tibbe GJM. Semipreparative purification and validation of monoclonal antibodies for immunotherapy in mice. $J$ Immunol Methods 1994; 172: 33-42.

6 Cobbold SP, Martin G, Qin S, Waldman H. Monoclonal antibodies to promote marrow engraftment and tissue graft tolerance. Nature 1986; 323: 164-66.

7 Via CS. Kinetics of T cell activation in acute and chronic forms of murine graft-versus-host disease. $J$ Immunol 1991; 146: 2603-609. 